\title{
Space Law (2019)
}

\author{
Diego Zannoni*
}

The aim of this analysis is to describe and assess developments and initiatives concerning disasters which took place in 2019 in the outer space legal arena. The focus will be on three distinct but connected issues: the use of outer space for the prevention and management of disasters on Earth; outer space as the place where disasters may occur due to the increasing congestion of orbits around Earth with space debris; and outer space as a potential source of disaster, i.e. the threat posed by asteroids crossing Earth's trajectory. Our attention will focus on the United Nations Committee on the Peaceful Uses of Outer Space (copuos) which, in its annual reports, constantly addresses these issues.

\section{The Committee on the Peaceful Uses of Outer Space}

Shortly after the launch of the first artificial satellite - Sputnik - copuos was established as an ad hoc committee by means of UNGA resolution 1348 (XIII), adopted on 12 December $1959,{ }^{1}$ and the following year became permanent via UNGA resolution 1472 (XIV). ${ }^{2}$ This subsidiary organ of the General Assembly, under Article 22 of the UN Charter, has a limited number of members, which has grown from 24 to its current 95. Its internal division into two sub-committees, the Scientific and Technical Sub-committee and the Legal Sub-committee, was created to link the legislative process of international space law with the rapid advances in technology and science. Its precise task is to promote international cooperation and study the 'nature of legal problems which may arise from the exploration of outer space'. ${ }^{3}$

* Researcher in International and European Union Law, University of Padua.

1 UNGA Res 1348 Question of the Peaceful Use of Outer Space (13 December 1958) UN Doc A/RES/1348 (XIII).

2 UNGa Res 1472 International Co-operation in the Peaceful Uses of Outer Space (12 December 1959) UN Doc A/REs/1472 (XIV).

3 Ibid., para. 1 (a), (b). The ILC has only made occasional reference to certain legal aspects of space activities in its Draft Articles, while it has never engaged in the codification or progressive development of space law. See ILC, 'Draft Articles on Prevention of Transboundary Harm 
As a rule, copuos adopts treaties and resolutions per consensus and submits them to the UN General Assembly for final approval. ${ }^{4}$ This procedure guarantees that the instruments adopted respect the interests of the most affected States, primarily space powers. As a matter of fact, a single opposition may obstruct the adoption of a resolution or treaty. It was successful during the Cold War when the two major powers, the United States and Soviet Union, were actively engaged in outer space. Since the world was divided into two blocks, their consent alone was sufficient for the adoption of any international norm on space matters.

Nevertheless, the end of the Cold War brought important changes to the new field of space law. While the preeminent space powers sought to maintain their influence and cutting-edge technologies, more and more States became directly or indirectly involved in outer space. This has challenged the space lawmaking process and made consensus increasingly difficult to achieve. COPUOS therefore began to gradually lose its initial impetus. Following the adoption of the Moon Agreement in 1979, ${ }^{5}$ law-making activities related to outer space slowed down and copU os has only adopted non-binding guidelines.

The issues dealt with herein were not even abstractly conceivable when the space treaties were drafted, and they consequently lack any specific regulation. It is therefore particularly interesting and challenging to follow the evolution of States' relative positions within COPUOs, and their efforts to tackle them, also through de iure condendo proposals. We will assess whether specific recommendations have been or are about to be adopted, and the role they might play within the space law framework.

\section{The Use of Outer Space for Disaster Prevention and Management}

Remote sensing can greatly contribute to the prevention and management of disasters. The Sendai Framework for Disaster Risk Reduction 2015-203o coherently includes two articles with explicit references to and emphasis on the

from Hazardous Activities with Commentaries', 2001, UN Doc A/56/10, paras. 4 and 10 of the Commentary to art. 1 (Scope).

4 See the Compendium on rules of procedure and methods of work related to the United Nations Committee on the Peaceful Uses of Outer Space and its Subsidiary Bodies (5 April 2016) UN Doc A/AC.105/C.2/2016/CRP.5.

5 Agreement Governing the Activities of States on the Moon and Other Celestial Bodies, 18 December 1979 . 
importance of satellite Earth observation and several articles refering to topics for which satellite observations are needed (e.g., geospatial information or risk maps). ${ }^{6}$

In particular, remotely sensed images can provide information to better understand Earth's surface, enabling proper use of its natural resources. These images can be applied to study and monitor the land structure in relation to landslides, seasonal river and flooding patterns, and the composition of snow in relation to avalanches ('risk-evaluation' and 'vulnerability-analysis'). ${ }^{7}$ High-resolution optical images are used to detect an impending disaster, for instance the propagation of fine dust, yellow dust, smog and smoke from forest fires, and localized heavy rains ('early-warning'). ${ }^{8}$ When a disaster has already occurred, remotely sensed images offer an immediate and comprehensive picture of the area affected. They are used to organize rescue operations and for an accurate evaluation of disaster losses.

Given the role space activities may - and indeed already - play in disaster prevention and management, it is not surprising that the Scientific and Technical Subcommittee's agenda item 8 is specifically entitled 'Space-system-based disaster management support', and that copUos takes stock of international practice in the field each year within its final report.

A number of systems, such as the International Charter on Space and Major Disasters ${ }^{9}$ and Sentinel Asia, ${ }^{10}$ provide sensed data in the event of disasters

$6 \quad$ Sendai Framework for Disaster Risk Reduction 2015-2030 (Sendai 2015) paras. 24, 25.

7 In a number of cases, sensed data have been used in international proceedings concerning environmental issues. In the case concerning Pulp Mills, Argentina claimed that an algal bloom was caused by the mill's emissions of nutrients into the river. To substantiate this claim, Argentina pointed to the presence of effluent products in the blue-green algal bloom and to various satellite images showing the huge concentration of chlorophyll in the water of the River Uruguay. ICJ, Case Concerning Pulp Mills on the River Uruguay (Argentina v. Uruguay) (Merit) [2010], ICJ Rep 2010, para. 248. In the Costa Rica v. Nicaragua case, both parties put forward satellite images in order to show the environmental consequences of the activities at stake. ICJ, Certain Activities Carried out by Nicaragua in the Boarder Area; Construction of a Road in Costa Rica along the San Juan River (Costa Rica v. Nicaragua) (Merit) [2015], ICJ Rep 2015, paras. 79-81, 202, 206.

8 See uncopuos Report, Sixty-second session (12-21 June 2019), UN Doc A/74/20, para. 135 [hereinafter 2019 UnCOPUOS Report].

9 The International Charter on Space and Major Disasters is a worldwide collaboration among space agencies, through which satellite-derived information and products are made available to support disaster response efforts. The Charter has been operational since November 200o. The text is available at <https://disasterscharter.org/web/guest/ text-of-the-charter $>$ last accessed (as any subsequent URL) on 7 April 2020.

10 Terms of Reference on the Joint Project Team for Sentinel Asia Step-3, available at <https:// sentinel-asia.org/e-learning/Documents/Terms\%2oof\%2oReference\%2ofor\%2oSA\%2O Step3.pdf >. 
both to States Parties and to third States. ${ }^{11}$ The information produced by the Copernicus Emergency Management Service is likewise, in principle, available to the public on a full, open and free-of-charge basis. ${ }^{12}$ In similar terms, the data policies of the WMO ${ }^{13}$ and EUMETSAT contemplate the provision of disaster-related data, even in favour of non-Member States. ${ }^{14}$

In its final 2019 Report, COPUOS underlines the success gained within these frameworks of co-cooperation, ${ }^{15}$ and constantly (but merely) emphasises the importance of space activities ${ }^{16}$ and of international cooperation ${ }^{17}$ for disaster prevention and management.

Such statements from copuos should not be underestimated. They raise awareness of these initiatives and encourage States to utilize and join them. Nevertheless, it seems that there is room for improvement, and for further and more far-reaching proposals. In particular, within the systems already in place, early-warning should be fostered alongside the post-disaster phase. ${ }^{18}$

11 Worthy of note is also the UN-SPIDER, which was established by the UNGA with Res 61/110 The United Nations Platform for Space-based Information for Disaster Management and Emergency Response (14 December 2006) UN Doc A/RES/61/11o.

12 Cf. Regulation (EU) 377/2014 establishing the Copernicus Programme [2014] OJ L 122, recital n. 36; art. 23; Commission Delegated Regulation (EU) 1159/2013 supplementing Regulation (EU) No 911/2010 of the European Parliament and of the Council on the European Earth monitoring programme (GMES) by establishing registration and licensing conditions for GMES users and defining criteria for restricting access to GMES dedicated data and GMES service information [2013] OJ L 309, art. 3 .

13 WMo Resolution 40, World Meteorological Congress (CG XII, 12th Meeting), wMo Policy and Practice for the Exchange of Meteorological and Related Data and Products Including Guidelines on Relationships in Commercial Meteorological Activities (26 October 1995) Annex I, paras. 7, 8 .

14 eumetsat Data Policy, Implementing Rules for meteosat Data and Products, art. 7 para. 4. Last amended on 1 January 2019.

152019 Scientific and Technical Subcommittee Report (28 February 2019) UN Doc A/ AC.105/1202, para. 153, 154, 155, 156, 159, 163, 2019 UnCOPUOs Report (n 8), paras. 130, 135.

162019 Scientific and Technical Subcommittee Report (n 15) paras. 28, 69, 84, 164; 2019 Legal Subcommittee Report, (18 April 2019), UN Doc A/AC.105/1203, para. 227; 2019 UNCOPUOS Report, (n 8), paras. 105, 267, 269 .

172019 Scientific and Technical Subcommittee Report, (n 15), paras. 98, 157, 164, 2019 UNCOPUOS Report (n 8) para. 102.

18 See the Russian Project to create the International Global Monitoring Aerospace System as a forward-looking new initiative for predicting and mitigating the consequences of natural and man-made disasters. Working paper submitted by the Russian Federation, UN Doc A/AC.105/C.1/L.323. For a reference to this project see UnCOPUOS Report, Fifty-fifth session (6-15June 2012) UN Doc A/67/20, para. 121. 
The international tendency is to strengthen the systems already in place, rather than create new ones. The multiplication of systems and the ensuing fragmentation could otherwise lead to difficulties in coordination in a sector where interoperability and multilateralism is apparently essential..$^{19}$ However, we are still a long way from achieving what is conceptually easy to conceive: i.e., global disaster management based on systematically recruited information coming from an international satellite network.

\section{$4 \quad$ The Spread of Space Debris}

Explosions in outer space due to the collision of two space objects or to the intentional destruction of a space object through anti-satellite weapons create hundreds to thousands of pieces of debris. For instance, in 2019 India destroyed one of its own satellites that was in low-Earth orbit. The entire international community may be affected by such operations. It is no exaggeration to claim that the spread of space debris may hinder the future exploration and use of outer space. Indeed, spacecraft may risk catastrophic collisions even with small space debris, and thus the prospects of exploring outer space would ultimately be reduced..$^{20}$ The use of orbits, which are limited natural resources, could be similarly affected. ${ }^{21}$ Space debris may even pose a serious threat to the lives of people on Earth. ${ }^{22}$

Some Outer Space Treaty provisions are relevant to this issue. For instance, Article IX of the Outer Space Treaty ${ }^{23}$ among other things obliges States Parties to undertake appropriate international consultations in cases of potentially harmful interference of their planned space activities with the space activities of other States Parties. The intentional destruction of a space object undoubtably falls within the scope of this rule. It is, however, well-known that Article IX is intrinsically weak insofar as it does not provide any specifications concerning the timing or other features of such consultations, and the legal

19 Madagascar, Paraguay and Peru had become members of the International Charter on Space and Major Disasters, while Eswatini, Ghana, South Africa, the Sudan, Tunisia and Zimbabwe had submitted applications. Cf. 2019 Scientific and Technical Subcommittee Report (n 15) para. 154.

202019 UnCOPUOS Report (n 8) paras. 71, 116.

21 Art. 44, International Telecommunication Union Constitution.

$22 \quad 2019$ UnCOPUOS Report (n 8) para. 37.

23 Treaty on Principles Governing the Activities of States in the Exploration and Use of Outer Space, Including the Moon and Other Celestial Bodies, 27 January 1967. 
consequences that would arise in case the States concerned are not able to reach an agreement. ${ }^{24}$

Given the lack of any specific rule on the matter, the UN General Assembly endorsed the copuos Space Debris Mitigation Guidelines, which in turn derived from the Space Debris Mitigation Guidelines of the Inter-Agency Space Debris Coordination Committee. ${ }^{25}$ Within the 2019 copuos report, recommendations were put on the table to further implement the Space Debris Mitigation Guidelines at the national level, ${ }^{26}$ or to encourage industry to voluntarily mitigate space debris. ${ }^{27}$ As long as national space legislations adopt the Space Debris Mitigation Guidelines as compulsory standards to follow, these per se non-binding instruments become binding by reference. ${ }^{28}$

Views regarding the next steps to take nonetheless differ. According to some States, since spacefaring Nations have an interest in preserving the safety and long-term sustainability of space activities, they will voluntarily take sound approaches to mitigating the problem of space debris. These approaches are unavoidably linked to evolving technologies and offer cost-benefit trade-offs. Therefore, it is claimed that it would be neither necessary nor opportune to develop legally binding space debris mitigation standards at present. ${ }^{29}$

This position has some elements of truth, but one cannot deny that States have an equivalent interest in preserving the safety and long-term sustainability of planet Earth. Merely relying on that interest has arguably not produced

24 In case consultations do not lead to a mutually acceptable settlement, art. 15 of the Moon Agreement contemplates a more detailed regulation.

25 Space Debris Mitigation Guidelines of the United Nations Committee on the Peaceful Uses of Outer Space (UN Doc A/62/20), endorsed by UNGA Res 62/217 (21 December 2007) UN Doc A/Res/62/217, para. 26; IADC Space Debris Mitigation Guidelines, IADC-O2-O1, Revision 1, 2007.

26 The Compendium of Space Debris Mitigation Standards Adopted by States and International Organizations allows to benefit from access to a comprehensive set of current instruments and measures on space debris mitigation. See the Compendium at <https://www.unoosa.org/documents/pdf/spacelaw/sd/Space_Debris_Compendium _COPUOS_25_Feb_2O19p.pdf $>$.

2019 Uncopuos Report (n 8) paras. 37, 67, 111, 227. See also UNGa Res 73/91 (7 December 2018), A/REs/73/91, para. 11.

28 In addition to the Space Debris Mitigation Guidelines, see the IADC Space Debris Mitigation Guidelines; the European Code of Conduct for Space Debris Mitigation (28 June 2004); ISO standard 24113:2011 (Space systems: space debris mitigation requirements); and ITU recommendation ITU-R S.1003 (Environmental protection of the geostationary-satellite orbit), which are all non-binding.

292019 Legal Subcommittee Report, (n 16), para. 163; 2019 Scientific and Technical Subcommittee Report, (n 15), para. 123. 
positive results so far. The coherent view has been expressed that binding rules for the sustainable conduct of space activities should be developed at the international level in order to foster predictability and uniformity, ${ }^{30}$ including an enhancement of the existing system of registering space objects. ${ }^{31}$

Different positions have even been expressed regarding the most concernprovoking action: the intentional destruction of space objects. Some delegations argue that it should be legally prohibited. In support of this view, they emphasise that the energy converted upon the impact of anti-satellite weapons, even in low-Earth orbits, renders any resulting space debris uncontrollable and hence increases the risk of collision. ${ }^{32}$ On the contrary, according to others, such destruction should be subject to specific criteria and procedures. ${ }^{33}$ The latter position is not irreconcilable with the former, as long as it maintains the prohibition of any intentional destruction of space objects as a rule. It also seems more suited to factual reality, because one cannot exclude that situations exist in which the destruction of a space object represents the "lesser evil". The Space Debris Mitigation Guideline n. 4 explicitly contemplates the case in which 'intentional break-ups are necessary', and specifies that they should be conducted at sufficiently low altitudes to limit the orbital lifetime of resulting fragments. Therefore, the real issue will be to establish appropriate criteria and procedures to minimise the risks when intentional destruction is unavoidable.

\section{The Collision of Earth with Asteroids}

Through remote sensing, outer space is used to manage disasters. Ironically, however, disasters can also "originate from space", for example when the trajectory of an asteroid crosses that of Earth. Such a risk might arguably become more concrete with the beginning of the exploitation of space resources. ${ }^{34}$

302019 Scientific and Technical Subcommittee Report, (n 15), paras. 124-125; 2019 Legal Subcommittee Report (n 16) para. 165; see also paras. 167, 168.

312019 Legal Subcommittee Report (n 16), para. 173. See the Convention on Registration of Objects Launched into Outer Space, 14 January 1975.

$32 \quad 2019$ Legal Subcommittee Report (n 16) para. 184.

332019 UnCOPUOS Report (n 8) para. 23 .

34 The United States and Luxembourg have already adopted national legislation regulating space mining. See United States, H.R.1508 - Space Resource Exploration and Utilization Act of 2015 , 114th Congress $\left(2015^{-2016)}\right.$ and Luxembourg, Law n. 674 on the Exploration and Use of Space Resources (20 July 2017). 
Indeed, through hard-to-predict cascading effects, mining asteroids could produce orbital changes that may set large rocks on a collision course with the Earth.

Within COPUOS awareness is increasing regarding the importance of information-sharing when discovering, monitoring and physically characterizing potentially hazardous near-Earth objects, in order to ensure that all countries can predict and mitigate impact with them. ${ }^{35}$ The space treaties do not contemplate specific provisions dealing with this issue. Article 5 para. 3 of the Moon Agreement is arguably the only provision which could be interpreted as contemplating a potential collision with an asteroid. ${ }^{36}$ Indeed, it obliges States Parties to 'promptly inform the Secretary-General, as well as the public and the international scientific community, of any phenomena they discover in outer space, including the Moon, which could endanger human life or health'. It therefore seems feasible that copUos will deal more comprehensively with this issue in the near future.

It looks as if the major contributions emanating from copUos with the aim of further developing space law in relation to the three areas under analysis will continue to take the form of sets of formally non-binding principles and guidelines. These may sooner or later - or possibly never - achieve the status of customary rules. Nevertheless, the role of non-binding principles should not be underestimated.

In the context of the use of outer space for disaster prevention and management, the data policies and regulations recalled above have a common feature. In line with the General Assembly Resolution on Remote Sensing Principles ${ }^{37}$

352017 Scientific and Technical Subcommittee Report (21 February 2017) UN Doc A/ AC.105/1138, paras. 205-210; Statement on Status report by the International Asteroid Warning Network (IAWN) and the Space Mission Planning Advisory Group (SMPAG) Submitted by the Chairpersons of IAWN and SMPAG (2 February 2017) UN Doc A/ AC.105/C.1/2017/CRP.25; 2019 Scientific and Technical Subcommittee, (n 15), paras. 210228; 2019 UnCOPUOS Report, (n 8), paras. 150-158. See also International cooperation in the peaceful uses of outer space (18 October 2019) UN Doc A/C.4/74/L.7, para. 12.

36 On the arguments supporting the interpretation proposed in the text, see Diego Zannoni, Disaster Management and International Space Law (Brill 2019) 194-195.

37 UNGA Res $41 / 65$ on Principles Relating to Remote Sensing of the Earth from Outer Space (3 December 1986) A/RES/41/65, Principles X and XI. Some delegations use Resolution $41 / 65$ as an argument to support the importance of promoting the availability 
and with COPUOS recommendations, ${ }^{38}$ they contemplate that, at least under certain conditions, data and assistance also be provided to non-Member States. This is undoubtedly linked to a growing awareness that the effects of disasters are never strictly limited to the directly affected State(s). ${ }^{39}$ However, at a closer look, such data policies and regulations, adopted and followed within and in conformity with the sound framework provided by the Outer Space Treaty, might correctly be classified as integrating and implementing the rule enunciated by Article I of the Outer Space Treaty, that is, that space activities shall be carried out for the benefit of all. The same goes for the guidelines that will arguably be adopted in the future against the threat posed by asteroids.

Along similar lines, space debris mitigation guidelines and standards could play an important role in determining fundamental notions such as "harmful interference" or "fault", which lack any definition in the space treaties. In other words, they could be used to assess whether States should undertake international consultations under the terms of Article IX OST, or to evaluate whether the conduct of a launching State constituted fault, for the purpose of determining its liability for damage caused by space debris in outer space. ${ }^{40}$ Thus, although the guidelines and standards are not legally binding, they could nevertheless facilitate the practical application of the Outer Space Treaty and the fault-based liability regime set out in the Liability Convention. ${ }^{41}$

of remote sensing data on a non-discriminatory basis. 2019 Legal Subcommittee Report (n 16) para. 196.

38 'States and international intergovernmental organizations should also undertake efforts to make relevant space-based information and data accessible to countries affected by natural disasters or other catastrophes, guided by considerations of humanity, neutrality and impartiality, and to support capacity-building activities aimed at enabling the receiving countries to make optimal use of such data and information. These spacebased data and information with appropriate spatial and temporal resolution should be freely, quickly and easily available for countries in crisis'. 2019 UnCopUos Report, (n 8), Guideline C.3, para. 4.

39 'A growing class of environmental problems, because they are regional or global in extent or because they affect the common international realm, will require extensive cooperation among Nations and action by international organizations in the common interest'. Stockholm Declaration on the Human Environment, 1972, point 7. 'The world is increasingly interdependent. All countries shall act in a new spirit of partnership to build a safer world based on common interests and shared responsibility to save human lives, since natural disasters do not respect borders'. Yokohama Strategy and Plan of Action for a Safer World, Guidelines for Natural Disaster Prevention, Preparedness and Mitigation, World Conference on Natural Disaster Reduction (Yokohama 1994), 2.

$40 \quad 2019$ UnCOPUOS Report (n 8) paras. 200, 233.

41 Convention on International Liability for Damage Caused by Space Objects, 29 March 1972, art. III. 